\title{
Screening of Novel Materials for Biodiesel Production Through the Esterification of Oleic Acid
}

\author{
Silvana R. Matkovic ${ }^{1} \cdot$ Juliet F. Nilsson $^{2} \cdot$ María E. Fait $^{3} \cdot$ Susana R. Morcelle $^{3}$. \\ Laura E. Briand ${ }^{1}$
}

Received: 25 July 2016 / Accepted: 11 September 2016

(C) Springer Science+Business Media New York 2016

\begin{abstract}
The present contribution screens the specific activity of various inorganic and enzymatic based materials in the esterification of oleic acid that is typically used as a test reaction for the production of biodiesel from high free fatty acid feedstocks. The inorganic materials investigated in this contribution are bulk fosfotungstic heteropoly acid of the Wells Dawson structure $\mathrm{H}_{6} \mathrm{P}_{2} \mathrm{~W}_{18} \mathrm{O}_{62} \cdot n \mathrm{H}_{2} \mathrm{O}$ (HPA), as well as dispersed on titanium dioxide $18 \% \mathrm{w} / \mathrm{w}$ $\mathrm{H}_{6} \mathrm{P}_{2} \mathrm{~W}_{18} \mathrm{O}_{62} / \mathrm{TiO}_{2}$ and the insoluble cesium salt of the Wells Dawson heteropoly anion $\mathrm{Cs}_{2} \mathrm{H}_{4} \mathrm{P}_{2} \mathrm{~W}_{18} \mathrm{O}_{62}$. Additionally, the commercial biocatalyst Novozym ${ }^{\circledR} 435$ (immobilized lipase B of Candida antarctica) and a self-supported lipase of vegetable origin obtained from the latex Araujia sericifera (ASL) were studied among the materials of enzymatic nature. The density and accessibility of Brønsted acid sites have a key role in the specific activity of the fosfotungstic based heteropoly compounds. The HPA dispersed over an oxide support catalyzed the esterification of the fatty acid in a heterogeneous fashion with the highest activity
\end{abstract}

Laura E. Briand

briand@quimica.unlp.edu.ar

1 Centro de Investigación y Desarrollo en Ciencias Aplicadas -Dr Jorge J. Ronco CINDECA-CCT La Plata-CONICET, Calle 47 No 257, B1900AJK La Plata, Buenos Aires, Argentina

2 Depto. de Cs. Biológicas, Fac. Cs. Exactas, Centro de Biotecnología y Biología Molecular (IBBM)-CCT La Plata-CONICET, Universidad Nacional de La Plata, Calle 47 y 115, B1900AJK La Plata, Argentina

3 Depto. de Cs. Biológicas, Fac. Cs. Exactas, Centro de Investigación de Proteínas Vegetales (CIPROVE), Universidad Nacional de La Plata, Calle 47 y 115, B1900AJK La Plata, Argentina
(6.4 $\mu \mathrm{mol} \mathrm{mg} \mathrm{m}^{-1} \mathrm{~h}^{-1}$ at $85^{\circ} \mathrm{C}$ ) among the inorganic materials. In contrast, the enzymatic materials are more active at lower temperature than the inorganic ones. Particularly, ASL catalyzed the homogenous methanolysis with the highest specific activity $\left(30.7 \mu \mathrm{mol} \mathrm{mg}^{-1} \mathrm{~h}^{-1}\right.$ at $\left.40^{\circ} \mathrm{C}\right)$ at the lowest temperature among the materials assayed.

\section{Graphical Abstract}

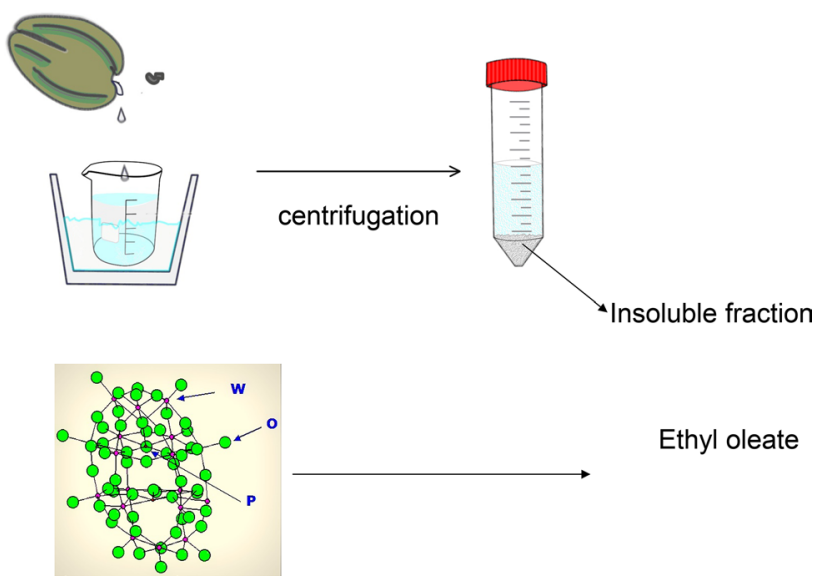

Keywords Heteropoly compounds - Lipases · Biofuels · Esterification · Free fatty acids

\section{Introduction}

Biodiesel is defined as the mono alkyl ester of long chain fatty acids derived from a renewable lipid feedstock, such as vegetable oil or animal fat. This fuel is one of the promising substitutes for the petroleum derivates fuels due to its 
environmental benefits and also because of the decreasing amount of petroleum reserves. Biodiesel is more biodegradable, has lower $\mathrm{CO}_{2}$ and sulfur emissions and almost none particulate pollutants, among other benefits compares with regular diesel [1-3].

Basic, acidic and enzymatic catalysts are currently investigated in order to develop new technologies in heterogeneous phase for the simplification of the production process of biodiesel [4]. In this context, it is well known that heteropoly compounds (HPCs) with Keggin structure are suitable catalytic materials in esterification [5]. For other hand, Matkovic et al. showed that Wells Dawson type has a higher number of acid sites and acid strength than the Keggin heteropoly acid, which makes it a promising material for the production of biodiesel [6].

Immobilized lipases are biocatalysts of growing interest in the field of biodiesel production from oil feedstock [7]. Novozym ${ }^{\circledR} 435$ is the commercial biocatalyst used industrially in production of biodiesel [8]. However, Novozym ${ }^{\circledR}$ 435 is a manufactured biocatalyst consisting in Candida antarctica lipase B immobilized in a metacrylate polymeric matrix, which makes it expensive for extensive use, and could produce harmful by-products when applied in this kind of systems by potential degradation of the support. An interesting alternative is represented by plant lipases, which are relatively easy to obtain [9]. In this sense, some plant latex-producing families such as Caricaceae, Euphorbiaceae, and Apocynaceae showed lipase activity [10]. From these lipases, Carica papaya latex lipase (CPL) has been, by far, the most studied in different industrial applications due to the abundance of this resource, its easy production and versatility [11]. Araujia sericifera (Apocynaceae), a native Argentinean milkweed which contains at least three proteases as some of their water-soluble components of its latex, showed also lipase activity in the insoluble fraction $[12,13]$. This lipase (named ASL), was characterized in terms of its hydrolytic and esterification activity, demonstrating to be an interesting alternative to Novozym ${ }^{\circledR} 435$ [14].

Online with the worldwide trend of developing new strategies to produce renewable fuels, this contribution presents the characterization and catalytic screening of inorganic and enzymatic materials as potential catalysts in biodiesel production.

\section{Materials and Methods}

\subsection{Materials}

The materials investigated in the esterification of oleic acid possess inorganic and enzymatic nature. The commercial biocatalyst Novozym ${ }^{\circledR} 435$ (batch LC20217 kindly donated by Novozymes) and a self-supported lipase of vegetable origin obtained from the latex of $A$. sericifera (ASL) were studied among the materials of enzymatic nature. The method of extraction of the vegetable lipase was published before [14].

Furthermore the inorganic materials comprise the bulk fosfotungstic heteropolyacid of the Wells Dawson structure $\mathrm{H}_{6} \mathrm{P}_{2} \mathrm{~W}_{18} \mathrm{O}_{62} \cdot n \mathrm{H}_{2} \mathrm{O}$ (HPA), as well as dispersed on titanium dioxide $18 \% \mathrm{w} / \mathrm{w} \mathrm{H}_{6} \mathrm{P}_{2} \mathrm{~W}_{18} \mathrm{O}_{62} / \mathrm{TiO}_{2}$. The synthesis of those materials was published before and the details are found in the literature [15]. Likewise, the insoluble cesium salt of the Wells Dawson heteropoly anion $\mathrm{Cs}_{2} \mathrm{H}_{4} \mathrm{P}_{2} \mathrm{~W}_{18} \mathrm{O}_{62}$ was also prepared and tested in the esterification of the fatty acid. In this context, the protons of the heteropoly acid were partially substituted with cesium according to the method described by Poźniczek et al. [16].

Finally, a mechanical mixture of $\mathrm{CsNO}_{3}(0.105 \mathrm{~g}$, Aldrich, 99\%) and the HPA (1.300 g) in the proportions mimicking the above salt was prepared. The cesium nitrate and the heteropoly acid were gently mixed and then calcined at $260^{\circ} \mathrm{C}$ for $4 \mathrm{~h}$ until the disappearance of the infrared signal of the nitrate.

\subsection{Esterification of Oleic Acid and Analytical Method}

The esterification of oleic acid was performed in a threeneck batch reactor equipped with a coolant to reflux, a teflon stirrer with speed regulation and a septum for sampling during the reaction. The reactor further comprises a glass insert in contact with the reaction medium to which a thermometer is added and an electric furnace with temperature control.

The experiments were performed by placing $20.00 \mathrm{~g}$ of oleic acid (Anedra, $61.5 \%$; density: $0.892 \mathrm{~g} / \mathrm{ml}$ ) into the reactor under stirring $(110 \mathrm{rpm})$. The catalyst and methanol (Carlo Erba, 99\%) are added to the system after the desired temperature is reached. In general, a 1:1 oleic acid:methanol molar ratio was used although a higher 1:4 ratio was also assayed in the case of the ASL lipase.

A series of blank experiments (similar conditions as described above without the addition of catalyst) were also performed at all the temperatures investigated. Additional experiments were conducted in order to establish the influence of external mass transfer. The catalytic tests were performed at different stirrer rates and also the addition of methanol was assayed through bubbling of a stream of air saturated with the alcohol.

The conversion of the oleic acid towards the methyl ester was followed through the determination of the acidity index according to the European normative UNE-EN 14104 [17]. In this context, a commercial solution of concentrated potassium hydroxide in ethanol $(\mathrm{KOH}$ in ethanol, $1 \mathrm{M}$ Carlo Erba) was used to prepare a $0.1 \mathrm{M}$ solution for titration of the fatty acid. The diluted solution was subsequently assessed against a primary standard such as, potassium 
hydrogen phthalate (Merck, $\geq 99.5 \%$ ). Additionally, a solution containing toluene (Anedra, 99.5\%) and ethanol (Carlo Erba, $99 \%$ ) in a $1: 1 \mathrm{v} / \mathrm{v}$ was also prepared according to the normative mentioned above.

The conversion of oleic acid was measured under initial conditions (i.e., low conversion range) in order to determine the intrinsic catalytic activity that allows a reliable comparison between the materials screened in the present investigation. In this context, the specific activity was calculated as the micromols of converted oleic acid per milligram of catalysts per time.

\section{Results and Discussion}

\subsection{Characterization of the Inorganic and Enzymatic Materials Through Infrared Spectroscopy}

The esterification of oleic acid with methanol was chosen as a reaction test in order to establish the catalytic activity of various inorganic and enzyme based materials such as: bulk $\mathrm{H}_{6} \mathrm{P}_{2} \mathrm{~W}_{18} \mathrm{O}_{62} \cdot x \mathrm{H}_{2} \mathrm{O}$ (HPA) and oxide supported ( $18 \%$ $\mathrm{HPA} / \mathrm{TiO}_{2}$ ) Wells Dawson heteropolyacid; the partially substituted HPA with cesium $\mathrm{Cs}_{2} \mathrm{H}_{4} \mathrm{P}_{2} \mathrm{~W}_{18} \mathrm{O}_{62}$, the mechanical mixture of $\mathrm{CsNO}_{3}$ and HPA mimicking the coprecipitated cesium salt; the commercial biocatalyst Novozym ${ }^{\circledR} 435$, and the self supported lipase of $A$. sericifera (ASL). The Fig. 1a, b, c show the infrared spectra of the materials based on the fosfotungstic Wells Dawson heteropolyacid between 2000 and $400 \mathrm{~cm}^{-1}$ wavenumbers; Novozym ${ }^{\circledR} 435$ and ASL in the same range, and all of them between 3700 and $2000 \mathrm{~cm}^{-1}$ wavenumbers, respectively.

The fosfotungstic heteropoly acid based materials possess the characteristic signal at $1088-1090 \mathrm{~cm}^{-1}$ ascribed to the stretching vibration of the $\mathrm{P}-\mathrm{O}$ species of the Wells Dawson heteropoly anion [18]. The signals at $1600-1662 \mathrm{~cm}^{-1}$ and the broad one centered at about $3400 \mathrm{~cm}^{-1}$ correspond to the bending modes $\delta(\mathrm{O}-\mathrm{H})$ of water and the stretching of the O-H species, respectively (see Fig. 1a, c). Additionally, the signals at 961,909 and $775 \mathrm{~cm}^{-1}$ (not observed in the oxide supported HPA due to the strong absorption of titanium dioxide) are assigned to the vibration of the $\mathrm{W}-\mathrm{O}$ species that compose the cage surrounding the central $\mathrm{P}-\mathrm{O}$ species (see Fig. 1a).

It is worth noticing that the oxide supported heteropoly acid was synthesized at the theoretical dispersion limit loading of tungsten atoms per $\mathrm{nm}^{2}$ of titanium dioxide that corresponds to 11 atoms per $\mathrm{nm}^{2}$ or $18 \mathrm{wt} \%$. However, previous studies of some of us demonstrated that such percentage exceeds the monolayer coverage providing crystals of HPA over the $\mathrm{TiO}_{2}$ [15]. Particularly, the dispersion over the oxide support provided a higher surface area than the non-supported materials $\left(49.9 \mathrm{~m}^{2} \mathrm{~g}^{-1}\right.$ of the supported HPA vs. $\sim 1 \mathrm{~m}^{2} \mathrm{~g}^{-1}$ of the bulk HPA) without perturbing the heteropoly anion structure. The presence of the characteristic Brønsted acid sites of the Wells Dawson heteropoly anion based materials such as, bulk and supported HPA, cesium salt, and the cesium nitrate-HPA mixture, is evidenced by the infrared signal at $\sim 3400 \mathrm{~cm}^{-1}$ (see Fig. 1c). The cesium salt was synthesized through the partial substitution of the acid sites with the alkaline element in order to obtain an insoluble material and somehow tune the acidity of the material. Previous investigations demonstrated that the replacement of protons of the fosfotungstic heteropolyacid with cesium ions diminishes its acidity. The studies of Matachowski et al. demonstrated that the higher the amount of cesium in the $\mathrm{Cs}_{\mathrm{x}} \mathrm{H}_{3-\mathrm{x}} \mathrm{PW}_{12} \mathrm{O}_{40}(\mathrm{X}=2,2.5,3)$ Keggin salt the lower the acidity [19].

The mixture between cesium nitrate and the HPA was synthesized in order to mimic the coprecipitated cesium salt described before. The use of this mixture as catalytic material will provide evidences of the role of the heteropoly acid in the esterification of the fatty acid as will be discussed later on.

The Fig. 1b shows the infrared spectra of Novozym ${ }^{\circledR} 435$ that is the well known commercial biocatalyst composed by the lipase $\mathrm{B}$ of $C$. antarctica (an enzyme of fungal origin) dispersed over beads of polymethylmethacrylate. Additionally, the naturally immobilized lipase found in the gums of the fruit of the native plant called A. sericifera is also shown [14]. In general, the spectra of both materials possess the characteristic infrared signals of the proteins such as the stretching vibration of the NH bond at $\sim 3300 \mathrm{~cm}^{-1}$ (known as Amide A); the Amide I due to the stretching vibration of the $\mathrm{C}-\mathrm{O}$ bond at $1650 \mathrm{~cm}^{-1}$; the Amide II that is the out-of-phase combination of the $\mathrm{NH}$ in plane bend and the $\mathrm{CN}$ stretching vibration at $1543 \mathrm{~cm}^{-1}$ and the Amide III signal ascribed to the in-phase combination of the $\mathrm{NH}$ bending and the $\mathrm{CN}$ stretching vibration at 1240 and $1170 \mathrm{~cm}^{-1}$ (see Fig. 1b, c) [20]. In the particular case of Novozym ${ }^{\circledR} 435$, the intense signal at $1735 \mathrm{~cm}^{-1}$ corresponds to the polymeric matrix that supports the lipase (PMMA polymethylmethacrylate).

The signals at 1451 and $1379 \mathrm{~cm}^{-1}$ attributed to the asymmetric $\delta_{\text {as }}\left(\mathrm{CH}_{3}\right)$ and symmetric $\delta_{\mathrm{s}}\left(\mathrm{CH}_{3}\right)$ bending of methyl groups respectively, are clearly seen in the infrared spectra of the ASL. Additionally, the asymmetrical $v_{\mathrm{as}}\left(\mathrm{CH}_{2}\right)$ and symmetric $v_{\mathrm{s}}\left(\mathrm{CH}_{2}\right)$ stretching of the methylene groups appears at 2924 and $2854 \mathrm{~cm}^{-1}$, respectively [21].

The investigation reported by Palomino-Schätzlein et al. demonstrated the complexity of the composition of the crude extract of the plant $A$. Sericifera. The leaf extract of the plant possesses a variety of triterpene esters, free esters, free carboxylic acids between others [22]. In this context, the signal at $1712 \mathrm{~cm}^{-1}$ of ASL could be ascribed to the carbonyl stretching vibration of triterpenoids and the vibration 

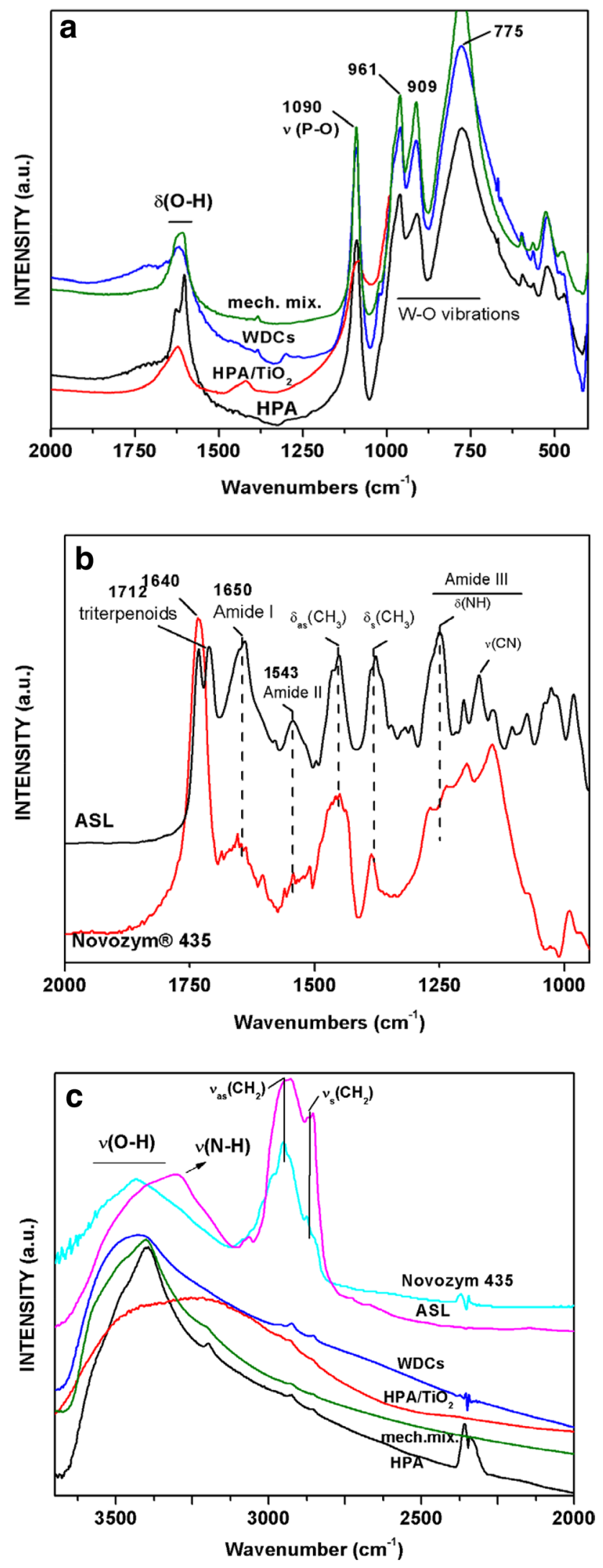

4Fig. 1 a Infrared spectra of bulk fosfotungstic heteropoly acid $\mathrm{H}_{6} \mathrm{P}_{2} \mathrm{~W}_{18} \mathrm{O}_{62} \cdot x \mathrm{H}_{2} \mathrm{O} \quad(\mathrm{HPA}) ; 18 \% \quad \mathrm{HPA} / \mathrm{TiO}_{2} \quad\left(\mathrm{HPA} / \mathrm{TiO}_{2}\right) ;$ Wells Dawson cesium salt $\mathrm{Cs}_{2} \mathrm{H}_{4} \mathrm{P}_{2} \mathrm{~W}_{18} \mathrm{O}_{62}$ (WDCs) and the $\mathrm{CsNO}_{3}$-HPA mechanical mixture (mech.mix.), in the range within $2000-400 \mathrm{~cm}^{-1}$ wavenumbers. b Infrared spectra of the commercial biocatalyst Novozym $^{\circledR} 435$ and the self supported lipase ASL in the range within $2000-400 \mathrm{~cm}^{-1}$ wavenumbers. c Infrared spectra of bulk fosfotungstic heteropoly acid $\mathrm{H}_{6} \mathrm{P}_{2} \mathrm{~W}_{18} \mathrm{O}_{62} \cdot x \mathrm{H}_{2} \mathrm{O}$ (HPA), $18 \% \quad \mathrm{HPA} / \mathrm{TiO}_{2}$ $\left(\mathrm{HPA} / \mathrm{TiO}_{2}\right) ; \mathrm{Cs}_{2} \mathrm{H}_{4} \mathrm{P}_{2} \mathrm{~W}_{18} \mathrm{O}_{62}$ (WDCs); the $\mathrm{CsNO}_{3}$ and HPA mechanical mixture (mech.mix.), the commercial biocatalyst Novozym ${ }^{\circledR} 435$ and the self supported lipase ASL within the $3700-2000 \mathrm{~cm}^{-1}$ range

of the aromatic $\mathrm{C}=\mathrm{C}$ stretching might be overlapping the signal of the Amide I that is centered at $1640 \mathrm{~cm}^{-1}[23,24]$. Additionally, the signal at $1732 \mathrm{~cm}^{-1}$ is characteristic of the absorption of $\mathrm{C}=\mathrm{O}$ of either $\alpha, \beta$ unsaturated or benzoate esters.

\subsection{Exploring the Catalytic Activity of Inorganic and Enzymatic Based Materials in the Esterification of Oleic Acid}

The progress of the esterification of oleic acid with methanol was followed through the acidity index and infrared spectroscopy of the reaction medium as described in the experimental section. The infrared analysis has been described in the literature as a reliable methodology for the identification of FAME (biodiesel) and quality determination [25].

The Fig. 2 shows the infrared spectra of oleic acid before and after being in contact with methanol in a 1:1 molar ratio at $85^{\circ} \mathrm{C}$ for $24 \mathrm{~h}$. Additional blank experiments were assayed at 40 and $65^{\circ} \mathrm{C}$ with a $1: 4$ and $1: 1$ oleic acid:methanol molar ratio, respectively. The results were similar to the ones obtained at $85^{\circ} \mathrm{C}$ therefore are not presented for brevity. Additionally, the figure shows the infrared spectra of the reaction media obtained after the esterification of the oleic acid with bulk HPA (200.0 mg, 1:1 oleic acid:methanol molar ratio, $\left.85^{\circ} \mathrm{C}\right), 18 \% \mathrm{HPA} / \mathrm{TiO}_{2}(200.0 \mathrm{mg}, 1: 1$ oleic acid:methanol molar ratio, $85^{\circ} \mathrm{C}$ ), Cs salt $(200 \mathrm{mg}, 1: 1$ oleic acid:methanol molar ratio, $85^{\circ} \mathrm{C}$ ), the mechanical mixture between cesium nitrate and the HPA (200 mg, 1:1 oleic acid:methanol molar ratio, $85^{\circ} \mathrm{C}$ ), Novozym ${ }^{\circledR} 435$ (200 mg, 1:1 oleic acid:methanol molar ratio, $65^{\circ} \mathrm{C}$ ) and ASL $\left(60.0 \mathrm{mg}, 1: 4\right.$ oleic acid:methanol molar ratio, $\left.40^{\circ} \mathrm{C}\right)$ for $24 \mathrm{~h}$. The conditions presented between brackets are the mass of catalytic material, the molar ratio between oleic acid and methanol and the temperatures, that are the optimum ones for the reaction to proceed.

The infrared spectra of the oleic acid before and after being heated at $85^{\circ} \mathrm{C}$ show the stretching vibration of the carbonyl $\mathrm{C}=\mathrm{O}$ group at $1712 \mathrm{~cm}^{-1}$. The position of this vibration is characteristic of dimeric species that are typically 


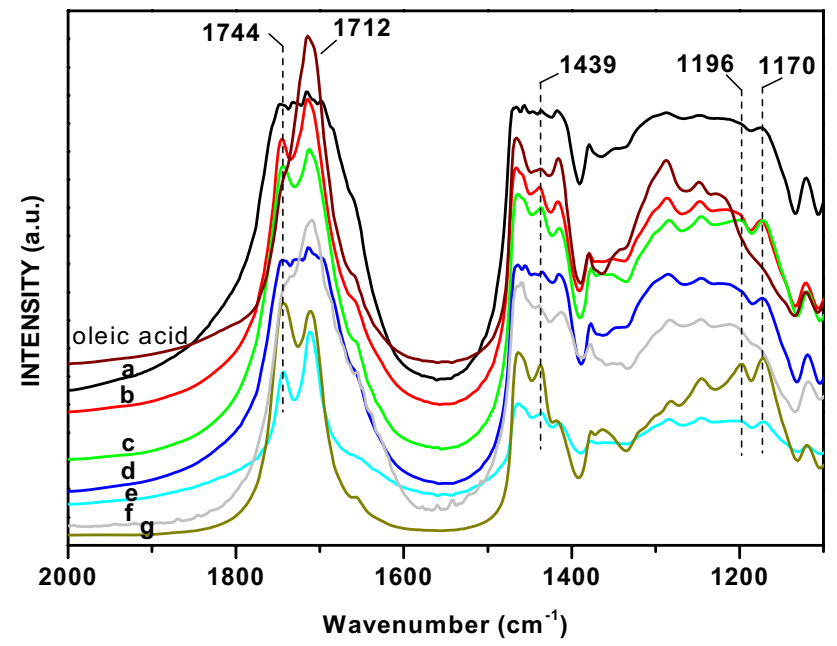

Fig. 2 Infrared spectra of pure oleic acid before and after being heated at $85^{\circ} \mathrm{C}$ with methanol (blank experiment called spectra $a$ ); bulk fosfotungstic heteropoly acid $\mathrm{H}_{6} \mathrm{P}_{2} \mathrm{~W}_{18} \mathrm{O}_{62} \cdot x \mathrm{H}_{2} \mathrm{O}$ (spectrum $b$ ), $19 \%$ $\mathrm{HPA} / \mathrm{TiO}_{2}$ (spectrum $c$ ); $\mathrm{Cs}_{2} \mathrm{H}_{4} \mathrm{P}_{2} \mathrm{~W}_{18} \mathrm{O}_{62}$ (spectrum $d$ ); the $\mathrm{CsNO}_{3}$ and HPA mechanical mixture (spectrum $e$ ); the self supported lipase ASL (spectrum $f$ ) and the commercial biocatalyst Novozym $^{\circledR} 435$ (spectrum $g$ )

formed due to hydrogen bonding of carboxylic acids at high concentrations. The intensity of this signal diminishes under reaction conditions while a new one at $1744 \mathrm{~cm}^{-1}$ appears. This last one is ascribed to the stretching vibration of the carbonyl group within the ester. More evidences of the presence of methyl oleate are found in the signals located at $1439 \mathrm{~cm}^{-1}$ due to of the asymmetric stretching of the methyl group in methyl ester, 1170 and $1196 \mathrm{~cm}^{-1}$ ascribed to the stretching of the $\mathrm{O}-\mathrm{CH}_{3}$ vibration [26-28]. It is worth noticing that the infrared spectrum of the Wells Dawson cesium salt does not show the characteristic signals of the methyl oleate described above. This observation coincides with the fact that is not catalytically active.
The Table 1 shows the catalytic performance of the materials expressed as micromoles of converted oleic acid per milligram of material per time (h) of reaction as a function of the temperature; mass of material and molar ratio of substrates (oleic acid:methanol). The inorganic materials catalyze the esterification of oleic acid at $85^{\circ} \mathrm{C}$ at stoichiometric molar ratio of the substrates (no activity was detected below that temperature). The specific activity of bulk HPA and $18 \% \mathrm{HPA} / \mathrm{TiO}_{2}$ were 1.10 and $6.40 \mu \mathrm{mol} \mathrm{mg} \mathrm{m}^{-1} \mathrm{~h}^{-1}$, respectively. The higher activity of the oxide supported than the bulk HPA is clearly associated to the higher density of accessible acid sites of the dispersed heteropoly anion vs the bulk one. Previous investigations indicated that the number of active acid sites of the Wells Dawson heteropolyacid supported over titanium dioxide is $3.1 \mu \mathrm{mol} \mathrm{m}^{-2}$ [6]. In contrast, the accessible acid sites of bulk $\mathrm{H}_{6} \mathrm{P}_{2} \mathrm{~W}_{18} \mathrm{O}_{62} \cdot x \mathrm{H}_{2} \mathrm{O}$ is directly related with the degree of hydration of the material due to the pseudo-liquid phase of the heteropolyanion. In fact, at $70^{\circ} \mathrm{C}$ (close to the temperature of the esterification of the oleic acid) the density of active sites of the HPA is $2.3 \mu \mathrm{mol} \mathrm{m}{ }^{-2}$ [29]. Moreover, the partial dissolution of the bulk HPA and the catalysis in the homogeneous fashion can not be ruled out since the heteropolyacid is soluble in alcohols.

The observation that the mechanical mixture was catalytically active $\left(1.66 \mu \mathrm{mol} \mathrm{mg}^{-1} \mathrm{~h}^{-1}\right)$ in contrast with the coprecipitated cesium salt $\mathrm{Cs}_{2} \mathrm{H}_{4} \mathrm{P}_{2} \mathrm{~W}_{18} \mathrm{O}_{62}$ provide more evidences the role of the acid sites in the esterification.

The esterification of the fatty acid with $18 \% \mathrm{HPA} / \mathrm{TiO}_{2}$ was carried under heterogeneous conditions as was verified by the absence of further reaction of the supernatant solution after separation of the catalyst and addition of methanol in excess. Interestingly, the heterogeneous esterification of the fatty acid was carried with low amount of methanol (1:1 oil:methanol molar ratio). This is somehow interesting

Table 1 Catalytic materials, molar ratio of oleic acid OA and methanol, mass of material, temperatures, specific activity and conversion (X\%) of the fatty acid to methyl oleate

\begin{tabular}{|c|c|c|c|c|c|}
\hline \multirow[t]{2}{*}{ material } & \multirow[t]{2}{*}{$\begin{array}{l}\text { OA:methanol } \\
\text { molar ratio }\end{array}$} & \multirow[t]{2}{*}{ mass $(\mathrm{mg})$} & \multicolumn{3}{|c|}{$\begin{array}{l}\text { Specific activity at indicated temperature (conversion \%) } \\
(\mu \mathrm{mol} \mathrm{mg}-1 \mathrm{~h}-1)\end{array}$} \\
\hline & & & $40^{\circ} \mathrm{C}$ & $65^{\circ} \mathrm{C}$ & $85^{\circ} \mathrm{C}$ \\
\hline $\mathrm{H}_{6} \mathrm{P}_{2} \mathrm{~W}_{18} \mathrm{O}_{6} \cdot x \mathrm{H}_{2} \mathrm{O}$ & $1: 1$ & 201.3 & - & No reaction & $1.1(8.5 \%)$ \\
\hline $18 \% \mathrm{HPA} / \mathrm{TiO}_{2}$ & $1: 1$ & 200.0 & - & - & $6.4^{\mathrm{a}}(8.9 \%)$ \\
\hline $\mathrm{Cs}_{2} \mathrm{H}_{4} \mathrm{P}_{2} \mathrm{~W}_{18} \mathrm{O}_{6}$ & $1: 1$ & 200.0 & - & - & No reaction \\
\hline Mechanical mixture & $1: 1$ & 199.0 & - & - & $1.66(12.8 \%)$ \\
\hline Novozym $^{\circledR} 435$ & $1: 1$ & 202.0 & - & $8.0(55.7 \%)$ & - \\
\hline \multirow[t]{4}{*}{ ASL } & $1: 1$ & 10.0 & No reaction & - & - \\
\hline & $1: 4$ & 10.7 & $60.7(16.1 \%)$ & - & - \\
\hline & $1: 4$ & 31.4 & $30.7(22.5 \%)$ & - & - \\
\hline & $1: 4$ & 61.6 & $14.2(21.9 \%)$ & - & - \\
\hline
\end{tabular}

${ }^{\mathrm{a}}$ The specific activity was expressed per amount of dispersed heteropolyacid over $\mathrm{TiO}_{2}$ that corresponds to $36 \mathrm{mg}$ of $\mathrm{HPA}$ for $200 \mathrm{mg}$ of material 
considering that the conventional process for the production of biodiesel catalyzed with $\mathrm{KOH}$ is carried under homogenous fashion at $70^{\circ} \mathrm{C}$ with a much higher oil to methanol molar ratio (typically, 1:10 oil:methanol molar ratio) [30].

Finally, is worth noticing that the specific activity obtained in this contribution $\left(6.4 \mu \mathrm{mol} \mathrm{mg} \mathrm{m}^{-1} \mathrm{~h}^{-1}\right)$ is similar to the one reported for the 12-tungstofosforic acid $\mathrm{H}_{3} \mathrm{PW}_{12} \mathrm{O}_{40}$ in the esterification of oleic acid with methanol $\left(8.0 \mu \mathrm{mol} \mathrm{mg}{ }^{-1} \mathrm{~h}^{-1}\right.$, OA:methanol molar ratio $\left.=1: 2.5\right)$ and ethanol $\left(8.8 \mu \mathrm{mol} \mathrm{mg}^{-1} \mathrm{~h}^{-1}\right.$, OA:ethanol molar ratio $\left.=1: 6\right)$ [31, 32].

Novozym ${ }^{\circledR} 435$ is a well known biocatalyst in the generation of biodiesel and in fact is being used at industrial level [33, 34]. Previous investigations by some of us in collaboration with Piedmont Biofuels demonstrated that the catalytic stability of Novozym ${ }^{\circledR} 435$ in the esterification and trans-esterification of vegetable oil towards FAME is not affected by the amount of free fatty acids of the feeding mixture, the ratio of FFA to methanol or even the source of such free fatty acids but to the presence of moisture [34]. Those investigations allowed determining the optimum temperature $\left(65^{\circ} \mathrm{C}\right)$ for the esterification/ trans-esterification of vegetable oils using Novozym ${ }^{\circledR} 435$. In this context, the same conditions were used to assay the esterification of oleic acid with the commercial biocatalyst in order to compare with the novel ASL lipase. Previous studies of the activity of ASL demonstrated that an optimum performance occurs at $40^{\circ} \mathrm{C}$ while a drastic drop of activity happens from $60^{\circ} \mathrm{C}$ and upwards [14]. The comparison of the specific activities of Novozym ${ }^{\circledR} 435$ and the self supported vegetable lipase, clearly demonstrate the higher activity (at a much lower temperature) of the ASL (see Table 1). Nevertheless, the commercial biocatalyst is active under stoichiometric molar ratio of substrates while the ASL requires an excess of methanol. The experiments also demonstrated that an increase of the mass of ASL above $10 \mathrm{mg}$ does not increase the specific activity. In fact, previous investigations on the synthetic activity of this lipase in esterification reactions showed a linear relationship between the conversion and the load of the biocatalyst in the reaction medium until it level off. At this point, the increase in the amount of lipase had no influence on the specific activity. This observation was attributed to the effect of enzyme agglomeration that prevents the access of the substrate to the active sites [14].

It is interesting to compare the catalytic activity of the ASL with the free $C$. antarctica lipase B that is the enzyme that composes Novozym ${ }^{\circledR} 435$. Free CALB lipase has been thoroughly investigated in the homogeneous esterification of oleic acid with various alcohols and reaction conditions [35]. Previous investigations reported that the catalytic activity of CALB $(1.7 \mathrm{mg})$ in the esterification of oleic acid with methanol at $32{ }^{\circ} \mathrm{C}$ and a $1: 2 \mathrm{OA}$ :methanol molar ratio is equal to $4.3 \mu \mathrm{mol} \mathrm{mg} \mathrm{m}^{-1} \mathrm{~h}^{-1}$. This value again is significantly lower than the activity of the ASL $\left(60.7 \mu \mathrm{mol} \mathrm{mg}^{-1} \mathrm{~h}^{-1}\right)$ investigated in this contribution.

Actually, the new technology for the production of biodiesel through an enzymatic process uses a liquid enzyme (Eversa ${ }^{\circledR}$ Transform commercialized by Novozymes) at $35^{\circ} \mathrm{C}, 0.3 \mathrm{wt} \%$ loading of enzyme per batch (compared with the $0.04 \mathrm{wt} \%$ of the ASL used in the present investigation) and a methanol:total fatty acid molar ratio of $1: 1.5$ [36]. A direct comparison of the catalytic activity is difficult since to the knowledge of the authors, there is not open literature about that novel biocatalyst.

\section{Conclusions}

The similarity between the catalytic performance of the Keggin and Wells Dawson HPAs and the observation that the partially substituted cesium salt proved no activity (the acid sites are partially replaced by a non acid counter-cation) are evidences of the key role of the Brønsted acid sites in the esterification of the fatty acid. The higher specific activity of the supported than the bulk Wells Dawson HPA also allows concluding that the reaction is controlled by the density of available surface acid sites instead of the well known pseudoliquid behavior of the HPA.

The self-supported ASL lipase (extracted from a native plant) was more active at a significantly lower temperature of reaction than the immobilized lipase Novozym ${ }^{\circledR}$ $435\left(60.7 \mu \mathrm{mol} \mathrm{mg}{ }^{-1} \mathrm{~h}^{-1}\right.$ at $40^{\circ} \mathrm{C}$ vs. $8.0 \mu \mathrm{mol} \mathrm{mg}^{-1} \mathrm{~h}^{-1}$ at $\left.65^{\circ} \mathrm{C}\right)$. Actually, the excess of alcohol required for the beginning of the reaction (1:4 oil:methanol molar ratio) caused the dissolution of the lipase that in fact, worked in a homogeneous medium. The comparison with reported values about the catalytic activity of the free lipase B of $C$. antarctica under similar reaction conditions indicates that the vegetable lipase is an order of magnitude more active than the fungal one. There is no doubt that the ASL is a promising biocatalyst in the esterification of free fatty acid and in turn, in the production of biodiesel.

Acknowledgments The authors acknowledge the financial support provided by Consejo Nacional de Investigaciones Científicas y Técnicas CONICET of Argentina (project PIP 11220130100171 CO and PIP 0150) and Universidad Nacional de La Plata (projects 11X-626 and 11X-682).

\section{References}

1. Marchetti JM, Errazu AF (2008) Fuel 87:3477-3480

2. Ivanoiu A, Schmidt A, Peter F, Rusnac LM, Ungurean M (2011) Chem. Bull. "POLITEHNICA" Univ. (Timisoara) 56(70):94-98

3. Chesterfield DM, Rogers PL, Al-Zaini EO, Adesina AA (2012) Chem Eng J 207/208:701-710 
4. Sani YM, Wan Daud WMA, Abdul Aziz AR (2014) Appl Catal A Gen 470:140-161

5. Hamad B, Lopes de Souza RO, Sapaly G, Carneiro Rocha MG, Pries de Oliveira PG, González WA, Andrade Sales E, Essayem N (2008) Catal Commun 10:92-97

6. Matkovic SR, Valle GM, Gambaro LA, Briand LE (2008) Catal Today 133-135:192-199

7. Zhao X, Qi F, Yuan Ch, Du W, Liu D (2015) Ren Sust En Rev 44:182-197

8. José C, Austic GB, Bonetto RD, Burton RM, Briand LE (2013) Catal Today 213:73-80

9. Moussavou Mounguengui RW, Brunschwig C, Baréa B, Villeneuve P, Blin J (2013) Prog Energ Combust 35:441-456

10. Fiorillo F, Palocci C, Soro S, Pasqua G (2007) Plant Sci 172:722-727

11. Campillo-Alvarado G, Tovar-Miranda R (2013) J. Mol Catal B Enz 90:49-60

12. Priolo NS, Morcelle del Valle S, Arribére MC, López L, Caffini N (2000) J Protein Chem 19:39-49

13. Obregón W, Arribére MC, Morcelle del Valle S, Liggieri C, Caffini N, Priolo N (2001) J Protein Chem 20:317-325

14. Di Santo Meztler P, Fait ME, Foresti ML, Morcelle SR (2014) Catal Sci Technol 4:1386-1394

15. Matkovic SR, Collins SE, Bonivardi AL, Bañares MA, Briand LE (2015) Phys Chem Chem Phys 17:8097-8105

16. Poźniczek J, Lubańska A, Mucha D, Bielański A (2006) J Mol Catal A Chem 257:99-104

17. UNE-EN 14104, Spanish normative AENOR (2003) Products of fats and oils. Methyl esters of fatty acids (FAME). Determination of acidity index

18. Valle GM, Matkovic SR, Gambaro LA, Briand LE (2007) The environmentally friendly synthesis of heteropolyacids, Chap. 5 . In: Regalbuto J (ed) Catalyst preparation. Science and engineering. CRC Press, Boca Raton, pp. 75-92
19. Matachowski L, Zięba A, Zembala M, Drelinkiewicz A (2009) Catal Lett 133:49-62

20. Barth A (2007) Biochim Biophys Acta 1767:1073-1101

21. Silverstein RM, Bassler GC, Morrill TC (1991) Infrared spectrometry, Chap. 3. In: Spectrometric identification of organic compounds, 5th edn. Wiley, New York, pp. 91-164

22. Palomino-Schätzlein $\mathrm{M}$, Escrig PV, Boira H, Primo J, PinedaLucena A, Cabedo N (2011) J Agric Food Chem 59:11407-11416

23. Saha S, Subrahmanyam EVS, Kodangala Ch, Shastry SC (2006) Der Pharma Chemica 3:28-37

24. Zou J-H, Dai J, Chen X, Yua J-Q (2006) Chem Pharm Bull 54:920-921

25. Zhang W-B (2012) Ren Sust En Rev 16:6048-6058

26. Rabelo SN, Ferraz VP, Oliveira LS, Franca AS (2015) Int J Env Sci Dev 6:964-969

27. Nakkash NB, Al-Karkhi SR (2012) Iraqi J Chem Petr Eng 13:13-25

28. O’Donnell S, Demshemino I, Yahaya M, Nwadike I, Okoro L (2013) Eur Int J Sci Tech 2:137-146

29. Gambaro LA, Briand LE (2004) Appl Catal A Gen 264:151-159

30. Macario A, Giordano G (2013) Catal Lett 143:159-168

31. Sepúlveda JH, Vera CR, Yori JC, Badano JM, Santarosa D, Mandelli D (2011) Quim Nova 34(4):601-606

32. Oliveira CF, Dezaneti LM, García FAC, de Macedo JL, Dias JA, Dias SCL, Alvim KSP (2010) Appl Catal A Gen 372:153-161

33. Ranganathan SV, Narasimhan SL, Muthukumar K (2008) Biores Technol 99:3975-3981

34. José C, Bonetto RD, Burton RM, Briand LE (2013) Catal Today 213:73-80

35. Rosset IG, Cavalheiro MCHT, Assaf EM, Porto ALM (2013) Catal Lett 143:863-872

36. The novozymes enzymatic biodiesel handbook at http://www. novozymes.com/en/solutions/bioenergy/enzymatic-biodiesel/ Enzymatic-Biodiesel-Handbook 